\title{
Motivation as Pedagogical Technique for Teachers: A Cross Comparison Between Public and Private Sector
}

\author{
Tariq Mahmood \\ PhD Research Fellow \\ College road Town ship, Lahore, Pakistan \\ Corresponding author: +923014981592tariq_903@hotmail.com
}

Dr. Mukhtar Ahmed, Ph.D

Regional Director (Gujranwala), Allama Iqbal Open University, Islamabad rd_gujranwala@aiou.edu.pk

Haleema Shoaib

PhD Research Fellow

University of Education, Division of Education College road Town ship, Lahore, Pakistan

\section{Muhammad Amin Ghuman}

PhD Scholar, International Islamic University Islamabad Senior Subject Specialist GHSS Eminabad (Gujranwala)

\section{Doi:10.5901/mjss.2013.v4n2p563}

\section{Abstract}

Paper mainly aims to diagnose the uses of teacher's motivational techniques for secondary grader students. It also provides importance of motivational techniques for the betterment of student's academic enhancement. It provides a clear comparative picture of public and private teachers about the use of motivational techniques to get the required objectives for students learning. It is evident from research studies that qualification and salary packages of government teachers are for better than that of private teachers, but the output is reverse. Keeping in view these issues the researcher conducted research on this topic. This study was carried out on a sample of 654 students from both public and private institutions. For data collection a three point rating scale was developed and administered by the researchers themselves and by post also from some institutions. There were twenty (24) statements and 18 main aspects in the questionnaire to test the designed hypotheses. Validation of the instrument was ensured by taking opinion from different experts in the field. As the basic purpose of this study was the investigation about the use of motivational techniques in public and private institutions, therefore, descriptive statistics were used to draw results. For data analysis purposes SPSS software was used. The findings narrated that teachers of both the sectors do not create intrinsic motivation among students. They also show anger and punish students during teaching. Findings also disclosed that teachers do not present models as a helping material which is a good academic technique for students to motivate them for learning.

\section{Introduction}

Education is one of the most important instruments that play their role in National Development. Not only in economic development but education plays its role in the overall development of the country. In developing countries, education is 
an effective tool in reducing poverty by building a viable workforce capable of competing in an increasingly competitive and global economy. Pakistan has also given great importance to the education since its foundation. The first All Pakistan Education Conference was held in Karachi in1947, although Quaid-e-Azam could not participate in the conference but he sent his message to the participants in the words which show their great concern about the matter of education "There is no doubt that the future of our State will and must greatly depend on the type of education we give to our children and the way in which we bring them up as future citizens of Pakistan" (Iqbal, 1993).

In any education system teaching is the main part and also has deep effects on that education system. Teaching is a very complicated and dynamic activity; it demands to take appropriate and flexible actions during teaching learning process. A number of steps are required for a quality teaching. Among these curriculum, teaching techniques and strategies and, evaluation methods, all should be aligned with each other (Tileston, 2004). Willingness of students as well as teachers is necessary for the effective completion of teaching learning process. Teaching process will result in zero in spite of effective teaching methods if students are non-motivated for this process. Motivation has been widely accepted by students, teachers and researchers as one of the main factors. They are seemed to agree that motivation is responsible for determining human behavior by energizing it. Tanaka (2005) asserted that teachers (being an external factor) have a greater impact on students' motivation. In other words we can say that instructor, his behavior and teaching style are the main sources which affect the motivational quality of students positively as well as negatively.

Generally, there are two things which become base for student's motivation i.e. motives and goals. Motives are relatively general needs or desires that uplift students to initiate purposeful actions, while on the other side, goals are more specific and to be used to explain the direction and quality of action (Thrash \& Elliot, 2001). These two aspects show that motivation is key to success in every field particularly in education.

Lens and Ulrich (2004) highlight the importance of motivation in this way. They are of the view that motivation can predict the future of students. Motivation is a theoretical construct which is used to explain the initiation and direction for quality of behavior for goal achievement (Maehr \& Meyer, 1997). In the same way Pintrich and Schunk (1996) are of the view that motivation is the directed process towards goal achievement by behavior modification.

Motivation is student's commitment, engagement for the completion of any academic task. Motivation is a comprehensive term and covers many aspects of student's personality improvements (Johnson, 2008). Motivation is basically arousal, selection and direction particularly continuity of behavior. Nairne (2003) discuss about the motivation specifically that in motivation behavior of the students is directed towards the achievement of some academic goals. Selection and design of good goals is also support for motivation. Passer \& Smith, (2001) also defines and interpret motivation as the goal-directed behavior. It is the stimulation of actions towards a particular goal where previously there was little or no attraction towards that goal. It means to push a right button to get a desired reaction.

Motivation is divided into two types i.e. intrinsic motivation and extrinsic motivation. There is great debate on this issue. Some psychologists are of the view that motivation is only intrinsic arousal but it may be due to external or internal factor. On the other side, some psychologists are very strict about the division of motivation.

Lepper \& Henderlong (2000) differentiate that intrinsic motivation and extrinsic motivation are relatively independent, and the level of motivation in one may be high or low independent of the other type of motivation. Deci and Ryan (2000) reviewed many studies on motivation and found that intrinsic desire to achieve something is better than extrinsic force or desire.

Wiseman \& Hunt (2001) are of the view that motivation is internal process which direct behavior, stimulate exploit, and results in a continuous efforts with the passage of time. It is an intrinsic element of human character which is exhibited through their behavior (Skollingsberg, 2003). It also includes perseverance and commencement to make efforts to complete the give tasks within and outside the classrooms (Patrick et al, 2000). As earlier explained, willingness to learning is at the key level for academic achievement. While discussing the key factors for teaching learning process Pintrich \& Shunk (2002) said that motivation has a great impact in all areas of teaching and learning either these areas related with teacher or students.

We are going through modern era where academic freedom to studwnts is considered their right. Particularly in the developed countries it became a big issue to motivate students for learning (Theobald, 2006). Teachers have to waste enough time to make the students willing to learn something. There is great number of teachers who complain that students are not willing to learn and it became a difficult and challenging task to make them willing (Daniels \& Arapostathis, 2005). Without knowledge of the ways and means of encouraging children's learning the teacher's task will become impossible (Denis Child, 2004).

Positive reinforcement is considered as a god motive for students motivation by many teachers. Most teachers enjoy delivering praise and most students enjoy receiving it for the completion of any task (Burnett, 2001). But sometimes 
some techniques produce negative results. Also the excessive use of motivational techniques may lose their importance and students may become addicted of these techniques. Kohn (1993) argues that the effectiveness of rewards has been exaggerated and that rewarding students for learning undermines their internal desire to achieve their goals.

Motivation does not exist in yes or no form. It is a matter of degrees, may be low, moderate or intense. Normally motivation is a complex process and requires multiple forces to enhance motivation. Students are motivated in different ways at different times and for different purposes. Mainly motivation results in four aspects.

1. Energize students to initiate activity.

2. Direct learners to achieve goals and satisfy needs.

3. Control behavior to determine performance.

4. Sustain activity for the achievement of goals if goal is not immediately available (Dash \& Dash, 2003).

The above pints show that motivation enhances learning. This is also evidenced by different research studies. Murdock \& Miller (2003) found many researches which show positive relationship between motivation and achievements of student. Motivation not only enhances the academic performance but it also links with achievements. In the same way motivation also affect the personality as well as behavior of the students (Stipek et al, 1998).

Many environmental factors are also very good motives for students to enhace their learning. As Pakistan is a developing country but still providing free education upto matriculation level by funding of many donor countries. In Pakistan there are two main streams of education in public and private sector. Facilities, environment and motivational techniques may vary in both the sectors because the results are different. Therefore, to know the level of motivation is necessary to understand the main aspects of both the sectors. Therefore, the researchers decided to conduct a research on the motivational techniques used by secondary school teachers to motivate their students.

\section{Interpretation and Discussion}

Basically there are two streams in our education system in Pakistan i.e. Government school and private schools. The researchers were to investigate the comparison between these two strata. Therefore, data were analyzed to assess the difference in the use of multiple techniques to motivate students in private and public school teachers.

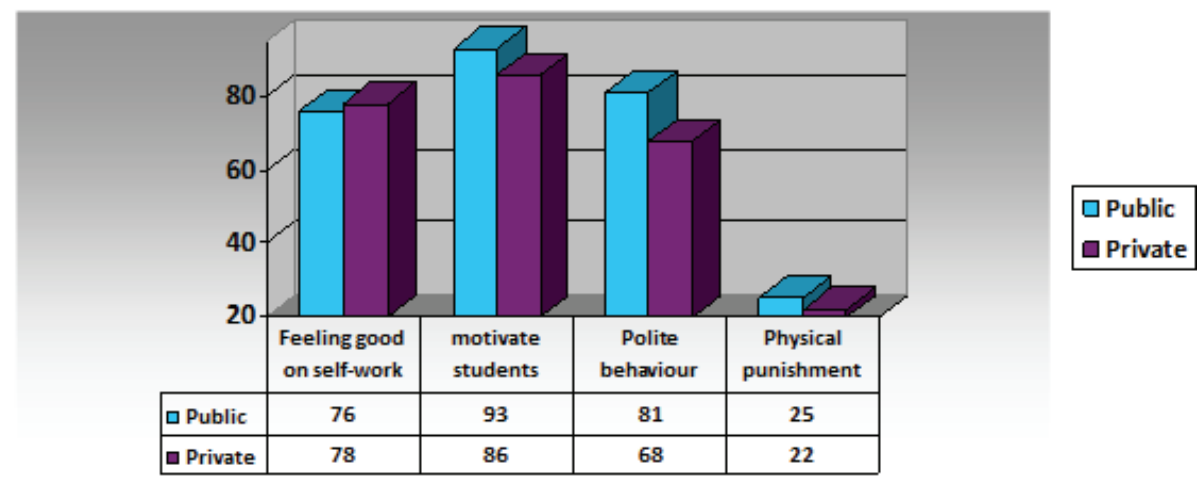

Figure 1: Graphical description between public and private sector

This research revealed (as depicted in the above figure) that teachers assign the responsibilities of self-work among students. This data disclosed that public and private sector teachers frequently allocate the duties of self-work to students with a slight difference. One of the major key factors to motivation the students is the active involvement of students in their own learning. Standing in front of them and lecturing is thus considered a relatively poor method of teaching. The reason is that students are not involved actively in lecture method. It is better to get students involved in activities, group problems solving exercises, helping to decide what to do and the best way to do it, working with one another or in some other ways getting physically involved in the lesson. This shows that if the teacher assigns students some task for completion, they devote their entire endeavor for the accomplishment of task. By this motivational technique students get themselves involved with heart and soul to achieve the objectives themselves. 
$86 \%$ teachers of private sector directly motivate their students for learning, while on the other side $93 \%$ teachers of public sector motivate their students in the classroom for better learning. This shows that government teachers motivate their students for learning in the classroom. Teacher's encouragement to motivate students for learning has a great importance in learning process. Competent teacher tries to create the intrinsic motivation among students by providing multiple means. Teachers have a very crucial role in the class. His/her feelings, emotions, sentiments and gestures greatly affect the students learning. If he displays anger, annoyance, irritate, furry and rage toward his students, they will definitely lose interest, attention, curiosity and concentration in the learning processes. Consequently, he will never get desired objectives which he sets in his lesson planning. It means teacher's attitude may motivate or de-motivate students.

The love and belonging needs are the major aspects of human psychological theories particularly Maslow's Hierarchy of Needs. $81 \%$ teachers in public sector and $68 \%$ teachers in private sector behave with their students with love and affection while teaching them. This data reveals that teachers of public sector show great affection and love toward their students. Love, affection, care, compassion and sympathy etc. are distinguished characteristics of teaching. Without these characteristics teaching is only to tame the animals.

The government of Pakistan has imposed a ban on corporal punishment in both private and government schools but majority of the teachers is disregarding the government instructions. In private institutions $22 \%$ teachers while in public sector schools $25 \%$ teachers physical punish their students when they do not learn their lesson or misbehave. Fear of physical punishment can memorize the lesson but it terminates the thinking process which is the core goal of the learning.

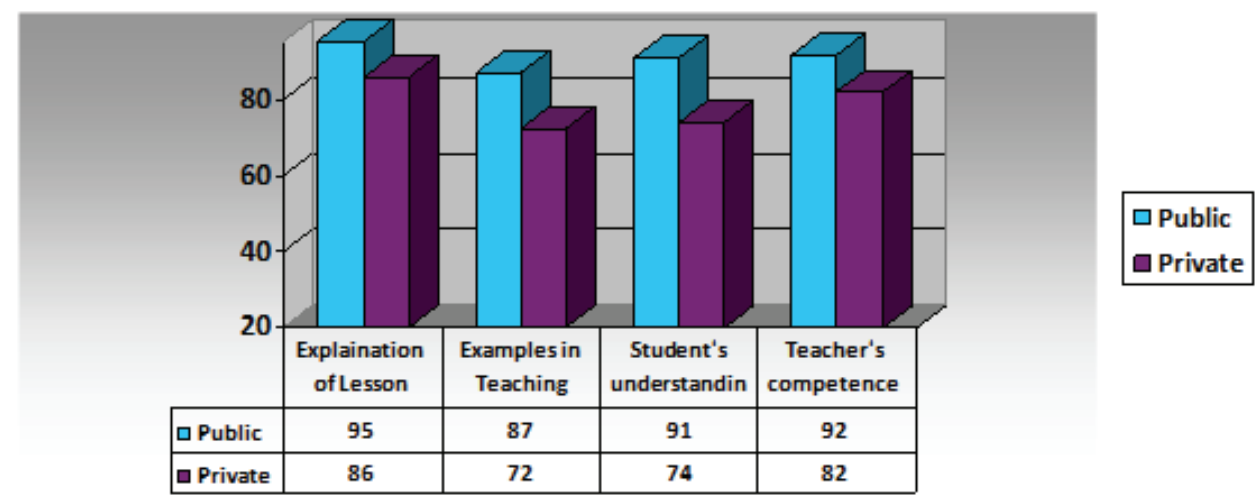

Figure 2: Graphical description between public and private sector

Explanation of the lesson makes the lesson more and more comprehensive for students particularly average students get more satisfaction. Form the above figure it is clear that teachers from public schools explain their lesson in a more detailed form as compared to private school teachers. The reason may be that in private schools non-competent and inexperienced teachers are working while in government sector experienced and qualified teachers are working. Examples during the teaching process make the lesson easy and understandable for students. If a teacher relates difficult ideas with daily uses examples, the students can understand those ideas with interest. In Pakistani educational institutions $87 \%$ public sector teachers provide daily life examples while teaching during the class. On the other side $72 \%$ private school teachers give example during his teaching. Glenberg et al (2004) described that young readers may not consistently furnish their lessons with real life examples and fail to derive much meaning from the text.

Proper guidance is the main factor of teaching because it helps the students so that concrete and substantial learning can occur. Students need help almost at every different and complicated task. Hence, it is the responsibilities of teachers to provide complete assistance to students. $91 \%$ public sector teachers provide proper guidance to make the lesson understandable for students, while in private sector only $74 \%$ got proper guidance. This shows that public sectors teachers help their students more and more for transmitting knowledge rather than private teachers. As the above figure show that competence level of public sector teachers is better as compared to the private school teachers. The reason may be that temporary appointment of private school teachers allures them to not preparing themselves over content. 


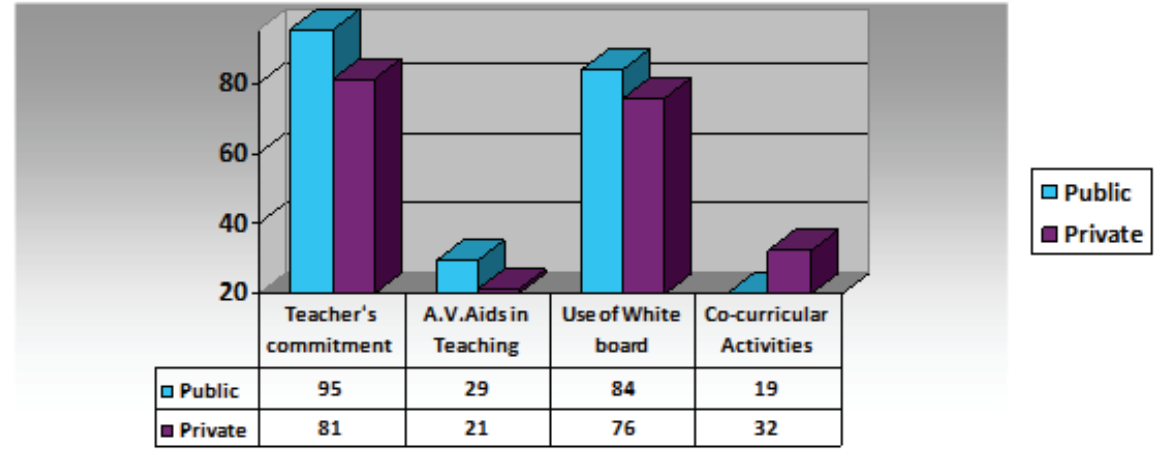

Figure 3: Graphical description between public and private sector

Teacher's commitment is one of the key elements in teaching learning process and is arguably becoming an increasingly important factor (Crosswell, 2006). In public sector schools 95\% teachers are committed to their teaching profession while only $81 \%$ teachers in private sector are committed and dedicated. Teacher's devotion disclose new and universal horizon and boost student desire for getting high goals. Although our school teachers are not paid high salaries and fringe benefits, however, they are presenting entire dedication for attaining set aims like increasing the literacy rate, eliminating the drop out ratio, and improving the quality in education etc. Teacher's dedication gives nation the status of nuclear power.

The data revealed that one third of the public and private school teachers never show charts and models during teaching learning process. In the same way one third of the teachers show these A.V. aids during teaching process. Charts and pictures present clear and implicit knowledge about the lesson. Charts and pictures give a very clear comprehension about the topic. The teacher who illustrates the charts and pictures his lesson is more interesting and attractive for children. The reason of this may be the non availability of the teaching aids because Pakistanis is spending very little amount on education system. White board is a good form of A.V. aids which is used by $84 \%$ public sector teachers and $76 \%$ private school teachers. The use of white board demands a teacher exhausting task. Normally it is observed that if a teacher has complete command over his topic then he/she will use the white board otherwise he/she will neglect this element. The teacher can explain his points, draws pictures, illustrations and graphs etc.

Co-curricular activities create invisible and unseen traits and attributes among students. There is a built-in list of these qualities like leadership, cooperation, equality, self-control, patience, tolerance, courage, sympathy, creative imagination and hard work etc. These characteristics can be developed by managing co-curricular activities in schools. Only $36 \%$ private institutes do not mange these co-curricular activities and $44 \%$ public schools also do not focus on these activities. This is a big flaw in both the education systems because this is an important motivational technique for students for learning as well as for physical fitness.

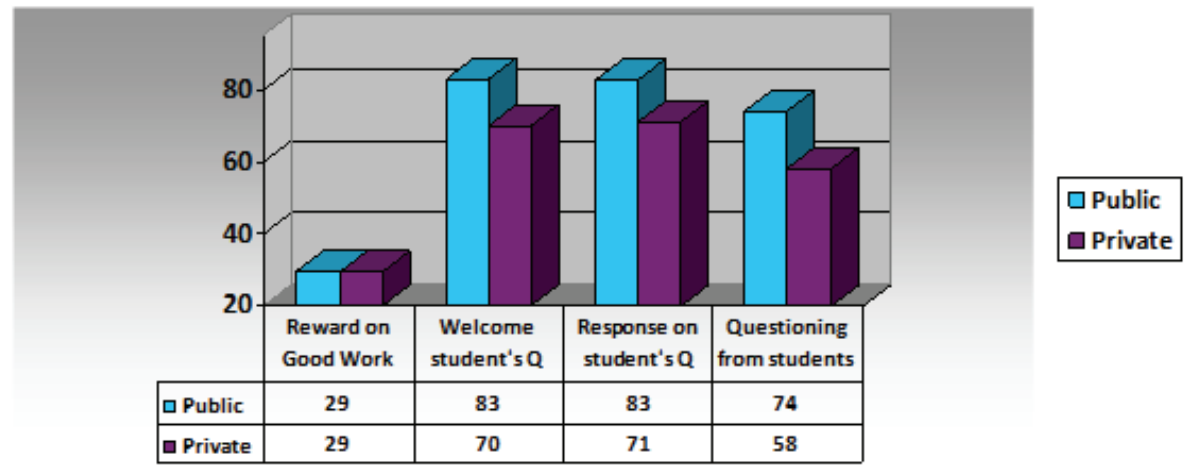

Figure 4: Graphical description between public and private sector 
Rewards provide extrinsic motivation to children. Rather than criticizing unwanted behavior or answers rewards correct behavior and answers. Achievement-based rewards during learning may increase participants' intrinsic motivation. A path analysis indicated that 2 processes mediated the positive effects of achievement-based rewards in learning and testing on intrinsic motivation. $41 \%$ private school teachers and $39 \%$ public school teachers never motivate students by endowing the rewards. Only few teachers both in public and private sector teachers provide rewards to students.

To make the students free to ask questions related to lesson for complete understanding is necessary for better learning. In public sector $83 \%$ teachers while in private schools $70 \%$ teachers welcome student's questions and answer them in a very pleasant way. These results show that public school teachers us these techniques better than the private school teachers. This technique to welcome the questions and respond them wholeheartedly is clear sign for positive behavior of teachers towards teaching and students.

Questioning session is the most important time in learning process. Questions of students from teacher and also questions of teachers from students are necessary for better learning. It is the responsibility of a teacher that he/she stimulates students for asking question during and after the lesson and give suitable answer in a happy and pleasant mood. He/she should appreciate students to ask questions during teaching. Questions can clear a lot of ambiguities about the topic. $74 \%$ teachers from public sector and $58 \%$ from private sector ask questions to evaluate outcomes of their teaching. Public sector teachers are more energetic in this regard than private school teachers.

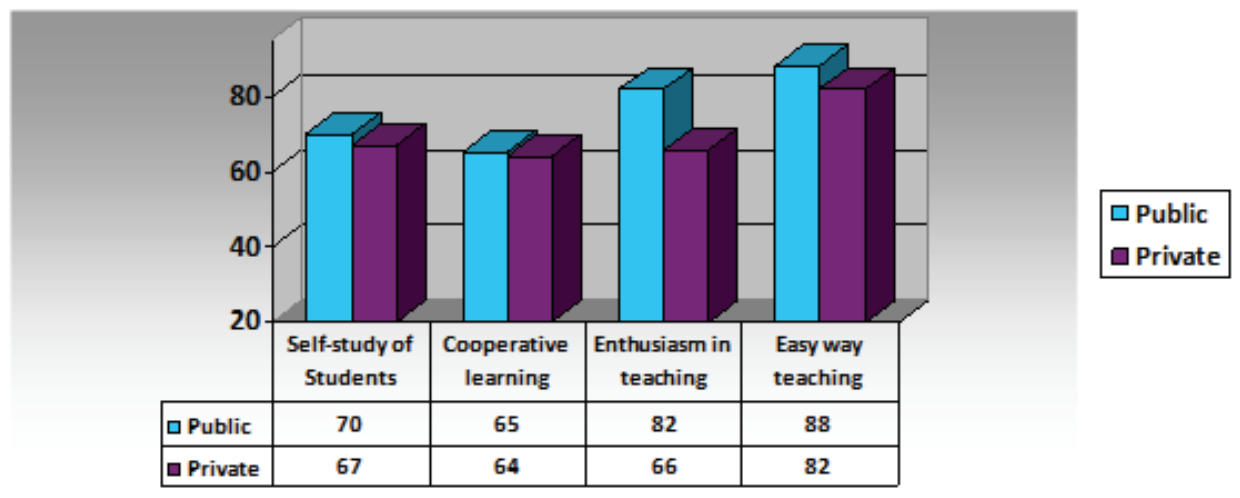

Figure 5: Graphical description between public and private sector

Research revealed that child centered teaching method is best method for effective learning. In this method students are given more opportunities to learn by active involvement in the teaching learning process. $70 \%$ teachers of the public sector and $67 \%$ teachers of the private sector are getting benefits from motivating their students through learning by doing method. Figures show that public sector teachers involve their students in learning process more than the teachers of the private sector. Student's participation in the lesson enhances the learning level of students.

Cooperative learning is one of the recommended teaching-learning techniques in which students achieve learning goals by helping each other in a social setting. Teaching and learning both are the main inter-related processes in the classroom. The importance of teaching method or instructional program is measured by its effectiveness, while the value of learning depends upon its application in the daily life. $65 \%$ of the public school teachers and $64.8 \%$ of private school teachers gain benefits from cooperative learning. Cooperative learning is seen as a powerful tool to motivate learning and has a positive effect on the classroom climate which leads towards high achievement.

Figure also show that teachers from public sector teach their students with enthusiasm and in an easy teaching way as compared to the teachers of the private sector. If the teacher is committed to the teaching profession he/she will be more effective and fruitful for that profession and ultimately will produce better results. From the above data it is clear that teachers from public sector are more committed to their job than private school teachers. Enthusiasm is a good and clear indicator of the committed person. 


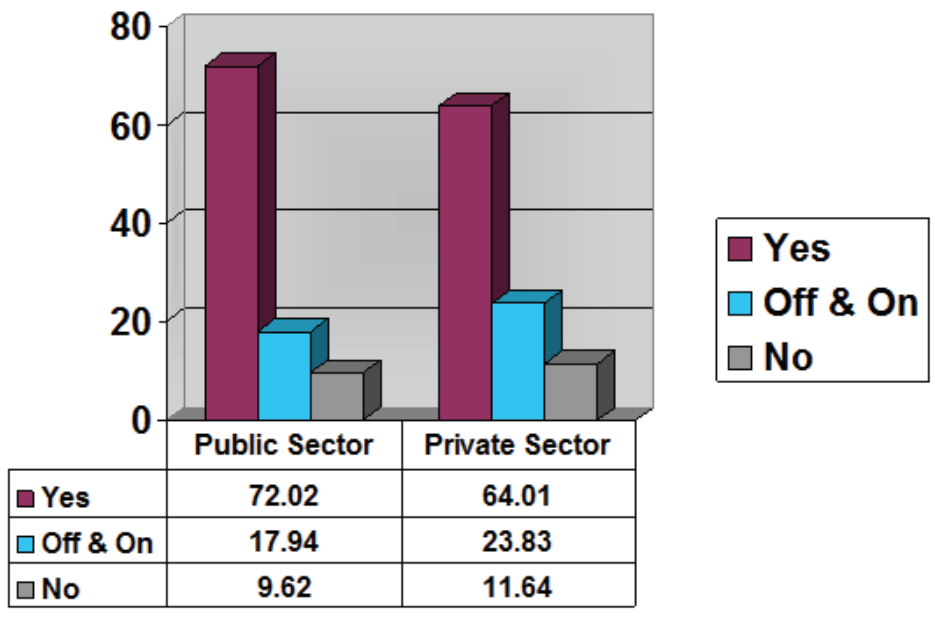

Figure 6: Overall Comparison of public and Private Sector

Above figure show an overall comparison between public and private teachers for the use of multiple motivational techniques to motivate their students. It is clear that public sector teacher use motivational techniques in very good way with a mean of percentage (72.02) while the private sector teachers use motivational techniques with the mean of percentage (64.01) which is less than the mean of public sector teachers.

On the basis of above results and discussion it is recommended that:

1. Exhibitions, educational tours and fares should be arranged at school level because these entertainments provide insights and intense interest among the students.

2. Co-curriculum activities should take place in schools because these can generate many moral, physical, mental and educational qualities in students.

\section{References}

Burnett, P. (2001). Elementary students' preferences for teacher praise. Journal of Classroom Interaction. 36.

Cameron, J. P., David, W., Banko, K., Gear, M., \& Amber. (2005). Achievement-Based Rewards and Intrinsic Motivation: A Test of Cognitive Mediators. Journal of Educational Psychology. 97(4).

Child, D. (2004). Psychology and the Teacher. (7th Ed.). London: Continum.

Crosswell, L. (2006). Understanding teacher commitment in times of change. Unpublished doctoral dissertation. Retrieved from http://adt.Caul.Edu.au

Daniels, E., \& Arapostathis, M. (2005). What do they really want? Student voices and motivation research. Urban Education. 40, 34-59.

Dash, M. \& Dash, N. (2003). Fundamentals of Educational Psychology. New Delhi: Atlantic Publisher and Distributors.

Glenberg, A. M. et al. (2004) Activity and Imagined Activity Can Enhance Young Children's Reading Comprehension. Journal of Educational Psychology. 96(3).

Iqbal, M. (1993) Education in Pakistan. Lahore: Aziz Publishers, Urdu Bazar.

Johnson, L. A. (2008). Relationship of instructional methods to student engagement in two public high schools. American Secondary Education, 36, 69-87.

Kohn, A. (1993). Punished by rewards: The trouble with gold stars, incentive plans, A's, praise, and other bribes. Boston: Houghton Mifflin.

Lens, E. \& Ulrich, E. (2004). The Teacher's Role in Motivating Students. Wayne State University. Retrived from:http://www.drchrustowski.com/Final_Paper_Motivation.pdf

Lepper, M., \& Henderlong, J. (2000). Turning "play" into "work" and "work" into "play." In C. Sansone \& J. Harackiewicz (Eds.), Intrinsic and extrinsic motivation: the search for optimal motivation and performance. San Diego: Academic Press. 
Maehr, M., \& Meyer, H. (1997). Understanding motivation and schooling: Where we've been, where we are, and where we need to go. Educational Psychology Review. 9, 371-409.

Murdock, T. B. \& Miller, A. (2003). Teacher as sources of middle school students' motivational identity: Variable-centered and person-centered analytic approaches. The Elementary School Journal, 103(4).

Nairne, J. S. (2003). Psychology the Adaptive Mind. (3rd Ed.) California: Thomson Ward worth.

Passer, M. W. \& Smith, E. R. (2001). Psychology Frontiers and Application. New York: McGraw Hill.

Patrick, B., Hisley, J., \& Kempler, T. (2000). "What's everybody so excited about?" The effects of teacher enthusiasm on student intrinsic motivation and vitality. The Journal of Experimental Education. 68, 217-236.

Pintrich, P. R., \& Schunk, D. H. (1996). Motivation in education: Theory, research, and applications. Englewood Cliffs, NJ: Prentice Hall.

Pintrich, P., \& Schunk, D. (2002). Motivation in education: Theory, research, and applications. Upper Saddle River, NJ: Pearson Education, Inc.

Skollingsberg, G. (2003). A comparison of intrinsic and extrinsic classroom motivational orientation of gifted and learningdisabled students. Roeper Review. 26.

Stipek, D., Givvin, K., \& Salmon, J. (1998). Can a teacher intervention improve classroom practices and student motivation in mathematics? The Journal of Experimental Education. 66,319-337.

Tanaka, T. (2005). 'Teacher influence on learner motivation'. Osaka Female Junior College, Retrieved from http://www.wilmina.ac.jp/ojc/kiyo_2005/kiyo_35_PDF/2005_06.pdf.

Theobald, M. (2006). Increasing student motivation: Strategies for middle and high school teachers. Thousand Oaks, CA: Corwin Press.

Thrash, T., \& Elliot, A. (2001). Delimiting and integrating achievement motive and goal constructs. In A. Efklides, J. Kuhl, \& R. Sorrentino (Eds.), Trends and prospects in motivation research. Boston: Kluwer.

Tileston D. W. (2004). What Every Teacher should know about Instructional Planning. California: Corwin Press, Thousand Oaks.

Wiseman, D., \& Hunt, G. (2001). Best practice in motivation and management in the classroom. Springfield, IL: Charles C. Thomas Publisher, Ltd. 